\title{
Samobójstwo w Dolinie Kościeliskiej, czyli prasa o śmierci Jadwigi Janczewskiej*
}

\author{
(opracował Tomasz Pawlak)
}

Sztuka Edycji 1/2016

ISSN 2084-7963 (print)

ISSN 2391-7903 (online)

s. $121-128$
Właściwie wszystko, co było do powiedzenia o samobójstwie narzeczonej

Witkacego - Jadwigi Janczewskiej - zostało zawarte w znakomitej rozprawie Stefana Okołowicza „Winy moje okropne”. Wokót samobójstwa Jadwigi Janczewskiej ${ }^{1}$. Poniżej przedstawiam wycinki prasowe o tej tragedii z ówczesnych gazet ${ }^{2}$. Jeśli nawet nie wnoszą one wiele do dotychczasowego stanu wiedzy ${ }^{3}$, mogą służyć za przyczynek do prasoznawstwa.

Pierwsze doniesienia o samobójstwie w Tatrach ukazały się w niedzielę 22 lutego 1914 roku. Na podstawie depeszy Wschodniej Ajencji Telegraficznej z 21 lutego „Kurier Warszawski” podaje: „Samobójstwo w Tatrach. Zakopane, 21 lutego. (Wsch. Aj. Tel.). W Dolinie Kościeliskiej pozbawiła się życia wystrzałem z rewolweru 22-letnia Zofia [!] Janczewska, rodem z Litwy" ${ }^{4}$.

Na podstawie doniesień własnego korespondenta z Zakopanego krakowska „Nowa Reforma” obszernie donosi tego samego dnia, jednak datując informacje na 22 lutego:

* Tekst pierwotnie ukazał się na portalu www.witkacologia.eu. Na potrzeby tego wydania został uzupełniony. ' Witkacy: bliski czy daleki? Materiały międzynarodowej konferencji z okazji 70. rocznicy śmierci Stanisława lgnacego Witkiewicza, Słupsk 17-19 września 2009, red. J. Degler, Słupsk 2013, s. 427-471.

Kwerenda objeła dostępne na połowe grudnia 2013 roku czasopisma znajdujace się w zasobach bibliotek cyfrowych oraz czasopisma ze zbiorów Biblioteki Uniwersytetu Warszawskiego - z jednym uzupełnieniem z końca 2015 roku.

${ }^{3}$ Uściślają miejsce i datę pochówku Janczewskiej oraz jej wiek.

„ „Kurier Warszawski” 1914, nr 53 (z 22 lutego), s. 19. Tę pierwszą chronologicznie depeszę ajencyjną podał historyk prasy zakopiańskiej, witkacolog, Maciej Pinkwart; M. Pinkwart, Wariat z Krupówek, Nowy Targ 2015, s. 143. 


\section{Samobójstwo w Dolinie Kościeliskiej}

(Telegr[am] „N[owej] Reformy”)

Zakopane, 22 lutego

Wczoraj po południu rozeszła się w Zakopanem pogłoska, że w Dolinie Kościeliskiej popełniła jakaś młoda panienka samobójstwo. Wiadomość okazała się prawdziwą. Ofiarą samobójczego zamachu padła Zofia Janczewska, licząca lat 22, rodem z Litwy. - Życiu swemu położyła kres wystrzałem z rewolweru.

Zakopane, 22 lutego

Według opowiadania górala, który przywiózł wiadomość o tragicznym wypadku, panna Janczewska wczoraj rano wynajęła jego powóz [na] wycieczkę do Doliny Kościeliskiej. Kiedy przybyli na miejsce, wyszła na zbocze góry i wystrzałem z rewolweru odebrała sobie życie. - Wszelki ratunek okazał się niemożliwy. Śmierć nastąpiła bezpośrednio po strzale, skierowanym w skroń.

Zakopane, 22 lutego

Na miejsce wypadku wyjechała wczoraj po południu komisja sądowo-lekarska.

Śp. Janczewska mieszkała na Bystrem w willi „Nosal”. Do Zakopanego przybyła celem poratowania zdrowia.

Zakopane, 22 lutego

Tragiczny zgon śp. Janczewskiej wywoła w Zakopanem powszechne współczucie.

Pobudki jakie skłoniły ją do desperackiego czynu, dotąd nieznanes.

Następnego dnia pojawia się korekta:

\section{Z kraju. Samobójstwo w górach}

Nasz korespondent donosi z Zakopanego: W uzupełnieniu wczorajszej wiadomości telefonicznej podaję następujące szczegóły: W sobotę po południu, zamieszkała w willi „Nosal” na Bystrem Jadwiga (nie Zofia, jak mylnie podano) Janczewska, lat około 23, z Królestwa Polskiego, pojechała sankami do restauracji w Dolinie Kościeliskiej, stamtąd zaś po wypiciu szklanki mleka udała się na przechadzkę, przykazawszy woźnicy czekać pół godziny. Po dłuższym oczekiwaniu zaniepokojony góral pojechał wyżej, chcąc dowiedzieć się, co się dzieje z pasażerką, i niedaleko od restauracji dowiedział się od pracujących tam robotników, że jakaś pani na zboczu leży nieżywa. Denatka leżała powyżej grot, na śniegu, z przestrzeloną na wylot piersią. Wieczorem około godz. 11 sprowadzono zwłoki do Zakopanego do kostnicy. O przyczynie samobójstwa różne obiegają wersje ${ }^{6}$.

Cóż z tego, że depesze z Zakopanego zostały skorygowane zaraz następnego dnia przez prawdopodobnie przebywającego na miejscu korespondenta gazety (który przekazywał informacje telefonicznie!), skoro już wszelkie dzienniki wszem wobec piszą o „Zofii Janczewskiej, lat 22, rodem z Litwy".

Warszawski „Goniec Poranny” donosi także w niedzielę, więc dzierży palmę pierwszeństwa z krakowską „Nową Reformą” i „Kurierem Warszawskim” - być może także miał własnego korespondenta w Zakopanem - „Samobójstwo. Zakopane (wł.). W Dolinie 
Kościeliskiej pozbawiła się życia wystrzałem z rewolweru 22-letnia Zofia Janczewska, rodem z Litwy"'.

Jednak we wtorek „Goniec Wieczorny” w dziale „Ziemie polskie” koryguje swoje doniesienia:

Samobójstwo w Zakopanem. W sprawie samobójstwa panny Janczewskiej przynoszą pisma szczegóły następujące: W sobotę po południu zamieszkała w willi „Nosal” na Bystrem p. Jadwiga (nie Zofia, jak mylnie podano) Janczewska, lat około 23, z Królestwa Polskiego, pojechała sankami do restauracji w Dolinie Kościeliskiej, stamtąd zaś po wypiciu szklanki mleka udała się na przechadzkę, kazawszy woźnicy czekać pół godziny. Po dłuższym oczekiwaniu zaniepokojony góral pojechał wyżej, chcąc dowiedzieć się, co się dzieje z pasażerką, i niedaleko od restauracji dowiedział się od pracujących tam robotników, że jakaś pani leży na zboczu nieżywa. Denatka leżała powyżej grot, na śniegu, z przestrzeloną na wylot piersią. Wieczorem około godz. 11 sprowadzono zwłoki do Zakopanego do kostnicy. O przyczynie samobójstwa różne obiegają wersje ${ }^{8}$.

Krakowski „Czas” podaje:

Pozbawiła się życia wystrzałem

$\mathrm{z}$ rewolweru 22-letnia

Zofia Janczewska, rodem z Litwy
Samobójstwo w Zakopanem. W Dolinie Kościeliskiej odebrała sobie onegdaj życie wystrzałem z rewolweru panna Zofia Janczewska, lat 22, rodem z Litwy. Zwłoki znaleźli przypadkowo w lesie przechodzący gajowi i wysłali zaraz wiadomość do Zakopanego. Nikt nie był świadkiem zamachu; nie pozostało też żadne pismo. Przyczyny samobójstwa są też dotychczas nieznane. W Zakopanem - jak nam stamtąd donoszą - przypuszczają, że powodem była nieuleczalna nerwowa choroba. Denatka mieszkała w pensjonacie pani Witkiewiczowej, gdzie miała bardzo troskliwą opiekę. Zwłoki sprowadzono do Zakopanego i złożono w kostnicy?.

Podobnie „Kurier Lwowski”:

Samobójstwo. W Zakopanem w Dolinie Kościeliskiej zastrzeliła się 22-letnia panna Zofia Janczewska, rodem z Litwy. Według opowiadania górala, który przywiózł wiadomość o tragicznym wypadku, panna Janczewska w sobotę rano wynajęła jego powóz na wycieczkę do Doliny Kościeliskiej. Kiedy przybyli na miejsce, wyszła na zbocze góry i wystrzałem z rewolweru odebrała sobie życie. Wszelki ratunek okazał się niemożliwy. Śmierć nastąpiła bezpośrednio po strzale, skierowanym w skroń. Mieszkała ona na Bystrem w willi „Nosal”. Do Zakopanego przybyła celem poratowania zdrowia ${ }^{10}$.

Następnego dnia ten sam „Kurier Lwowski” myli już (podane w poprzednim numerze poprawnie!) nazwisko denatki:

Samobójstwo Litwinki. Z Zakopanego donoszą: Zwłoki śp. Zofii Janiszewskiej [!], która odebrała sobie życie wystrzałem z rewolweru, przewieziono do kostnicy

7 "Goniec Poranny" 1914, nr 83 (z 22 lutego, niedziela), s. 6

" "Goniec Wieczorny" 1914, nr 89 (z 24 lutego), s. 3.

"Czas" 1914, nr 48 (z 23 lutego), s. 2.

${ }^{10}$ „Kurier Lwowski” 1914, nr 65 (z 23 lutego, wydanie popołudniowe), s. 4. 
w Zakopanem. Jak twierdzą, śp. Janiszewska [!] odebrała sobie życie z powodu nieuleczalnej choroby nerwowej ${ }^{11}$.

Wydawany w Krakowie „Ilustrowany Kurier Codzienny” wprowadza element romantyzmu, ale powiela słowo w słowo doniesienia „Nowej Reformy”:

Romantyczne samobójstwo w Dolinie Kościeliskiej. Zakopane, 23 lutego. Dawno już w Zakopanem nie było takiej sensacji dnia jak w sobotę, w którym to dniu rozeszła się wiadomość o romantycznym samobójstwie młodej panny zza kordonu. Pogłoski okazały się prawdziwymi, a jak później stwierdzono, ofiarą zamachu padła panna Zofia Janczewska, licząca lat 22, rodem z Litwy. Według opowiadania górala, który przywiózł wiadomość o tragicznym wypadku, panna Janczewska wczoraj rano wynajęła jego powóz na wycieczkę do Doliny Kościeliskiej. Kiedy przybyli na miejsce, wyszła na zbocze góry i wystrzałem z rewolweru odebrała sobie życie. Wszelki ratunek okazał się niemożliwy. Śmierć nastąpiła bezpośrednio po strzale, skierowanym w skroń. Na miejsce wypadku wyjechała wczoraj po południu komisja sądowo-lekarska. Śp. Janczewska mieszkała na Bystrem w willi „Nosal”. Do Zakopanego przybyła celem poratowania zdrowia. Tragiczny zgon śp. Janczewskiej wywołał w Zakopanem powszechne współczucie. Pobudki, jakie skłoniły ją do desperackiego czynu, dotąd nieznane ${ }^{12}$.

Nawet daleki od wydarzeń „Dziennik Poznański” podaje w dziale „Z różnych stron”:

„Samobójstwo w Tatrach. Z Zakopanego donoszą: W Dolinie Kościeliskiej pozbawiła się życia wystrzałem z rewolweru 22-letnia Zofia Janczewska, rodem z Litwy"13.

Skoro „rodem z Litwy”, to wileński „Kurier Litewski” podaje w dziale „Zza kordonu”: „Samobójstwo w Tatrach. W Dolinie Kościeliskiej pozbawiła się życia wystrzałem z rewolweru 22-letnia Zofia Janczewska, rodem z Litwy"14.

„Gazeta Lwowska” w dziale „Kronika” miała przynajmniej imperatyw wymienienia źródła podawanej przez siebie informacji:

Samobójstwo w Dolinie Kościeliskiej. Do „Nowej Reformy” donoszą z Zakopanego pod datą $22 \mathrm{bm}$.: Wczoraj po południu rozeszła się w Zakopanem pogłoska, że w Dolinie Kościeliskiej popełniła jakaś młoda panienka samobójstwo. Wiadomość okazała się prawdziwą. Ofiarą samobójczego zamachu padła panna Zofia Janczewska, licząca 22 lata, rodem z Litwy. Życiu swemu położyła kres wystrzałem z rewolweru. Według opowiadania górala, który przywiózł wiadomość o tragicznym wypadku, panna Janczewska wczoraj rano wynajęła jego powóz na wycieczkę do Doliny Kościeliskiej. Kiedy przybyli na miejsce, wyszła na zbocze góry i wystrzałem z rewolweru odebrała sobie życie. Wszelki ratunek okazał się niemożliwy. Śmierć nastąpiła bezpośrednio po strzale, skierowanym w skroń. Na miejsce wypadku wyjechała wczoraj po południu komisja sądowo-lekarska. Śp. Janczewska mieszkała na Bystrem w willi „Nosal”.

${ }^{11}$ „Kurier Lwowski” 1914, nr 66 (z 24 lutego), s. 2.

12 "llustrowany Kurier Codzienny” 1914, nr 45 (z 24 lutego), s. 2

13 "Dziennik Poznański” 1914, nr 44 (z 24 lutego), s. 4.

${ }^{14}$ „Kurier Litewski” 1914, nr 34 (z 11 lutego/24 lutego), s. 3. Podwójna data - według kalendarzy gregoriańskiego i juliańskiego, który obowiązywał na terenach Rosji aż do zakończenia I wojny światowej.

Śp. Janczewska mieszkała na Bystrem w willi „Nosal” 
Do Zakopanego przybyła celem poratowania zdrowia. Tragiczny zgon śp. Janczewskiej wywołał w Zakopanem powszechne współczucie. Pobudki, jakie skłoniły ją do desperackiego czynu, dotąd nieznane. Dziś donoszą nam telegraficznie z Zakopanego: Zwłoki śp. Zofii Janczewskiej przewieziono do kostnicy w Zakopanem. Jak twierdzą, śp. Janczewska odebrała sobie życie z powodu nieuleczalnej choroby nerwowej ${ }^{15}$.

Krakowski „Głos Narodu” w „Kronice zamiejscowej” podaje z kolei już właściwe imię denatki: „Samobójstwo w Dolinie Kościeliskiej popełniła w sobotę panna Jadwiga Janczewska, licząca lat 22, rodem z Litwy, strzeliwszy do siebie z rewolweru. Pobudki samobójstwa na razie nieznane"16.

„Gazeta Podhalańska” uniknęła kłopotów z imieniem - po prostu go nie zamieszczając:

Samobójstwo w Tatrach. W Dolinie Kościeliskiej odebrała sobie życie wystrzałem z rewolweru panna Janczewska z Królestwa Polskiego, licząca lat 22. Śp. Janczewska mieszkała w willi „Nosal” na Bystrem w Zakopanem. Zgon jej wywołał powszechne współczucie ${ }^{17}$.

„Kurier Warszawski” 7 marca w dziale „Korespondencje” podaje informacje o pogrzebie Janczewskiej, jednocześnie wskazując, że samobójczyni była córką znanego w Królestwie Polskim adwokata, byłego posła parlamentu rosyjskiego, Wiktora Janczewskiego ${ }^{18}$ :

Zwłoki śp. Jadwigi Janczewskiej, córki mecenasa Wiktora Janczewskiego, b. posła ziemi mińskiej do pierwszej Izby państwowej - tragicznie zmarkej w Zakopanem, przewieziono do Wilna i pochowano na cmentarzu Kalwaryjskim. Liczny zastęp bliższych i dalszych znajomych odprowadził zwłoki z dworca brzeskiego na cmentarz, gdzie po mszy św. złożono je do grobów rodzinnych ${ }^{19}$.

Krakowski „Czas” dwa dni później podaje tę samą informację:

Epilog tragedii w Zakopanem. Z Wilna donoszą: Zwłoki śp. Jadwigi Janczewskiej, córki adwokata Wiktora Janczewskiego, b. posła ziemi mińskiej do pierwszej Dumy, tragicznie zmarlej w Zakopanem, przewieziono do Wilna i pochowano na cmentarzu Kalwaryjskim. Liczny zastęp bliższych i dalszych znajomych odprowadził zwłoki z dworca brzeskiego na cmentarz, gdzie po Mszy św. złożono je do grobów rodzinnych ${ }^{20}$.

${ }_{15}^{15}$ "Gazeta Lwowska" 1914, nr 43 (z 24 lutego), s. 5.

${ }^{16}$ "Głos Narodu" 1914, nr 44 (z 24 lutego), s. 2.

${ }^{17}$ "Gazeta Podhalańska" 1914, nr 9 (z 1 marca), s. 8. Maciej Pinkwart podaje, że numer ukazał się 26 lutego; M. Pinkwart, op. cit., s. 143. Notabene tytuły zakopiańskie zadziwiająco mało pisały o tej tragedii, na co zwrócił uwagę Pinkwart: „Wychodzący w Zakopanem dwutygodnik "Zakopane«, w 1914 r. redagowany przez Józefa Diehla zupełnie bez jakiegokolwiek dziennikarskiego nerwu, pomija tę historię zupełnym milczeniem"; ibidem, s. 145.

${ }^{18}$ Wiktor Janczewski (1858-1922) - ziemianin, adwokat i działacz społeczny w Mińsku Litewskim, poseł miński do Dumy w 1906 roku. Z Jadwigą z Wiewiórskich Janczewską (1859-1920) mieli dwoje dzieci: Leona i Jadwigę; S. I. Witkiewicz, Dzieła zebrane, t. 17: Listy I, oprac. i przypisami opatrzył T. Pawlak, Warszawa 2013, s. 336, przypis 2 (Listy i notatki z podróży do tropików).

${ }^{19}$ „Kurier Warszawski” 1914, nr 66 (wydanie poranne, z 7 marca), s. 3.

${ }^{20}$ "Czas" dwa dni później 1914, nr 72 (z 9 marca), s. 2. 
Jednak Alwida A. Bajor z Wilna - specjalizująca się w dziejach rodów na Litwie oraz w biografii Witkacego - zwróciła uwagę, że miejsce pochówku jest mylne, bo opis (dworzec i cmentarz) wskazywałby raczej na ówczesny Mińsk Litewski, z którym związany był ojciec Jadwigi ${ }^{21}$.

Tak było w istocie. Potwierdza to znaleziona przeze mnie na pierwszej stronie „Kuriera Litewskiego” klepsydra z informacją o pochówku Jadwigi Janczewskiej w Mińsku Litewskim 5 marca (20 lutego) 1914 roku:

Śp. Jadwiga Janczewska, panna, zmarła w Zakopanem 8 (21) lutego rb., przeżywszy lat 24. Wyprowadzenie zwłok z dworca kolei Moskiewsko-Brzeskiej w Mińsku Litewskim nastąpi 20 lutego [tj. 5 marca wg kalendarza gregoriańskiego] o godz. 9-ej rano do kościoła na Kalwarii i tamże po mszy żałobnej pogrzeb, o czym zawiadamiają krewnych, przyjaciół i znajomych pogrążeni w rozpaczy Rodzice, brat i bratowa zmarłej ${ }^{22}$.

Zwraca uwagę w tej klepsydrze (co ważne, podany przez rodzinę) wiek zmarłej 24 lata. Wydaje się, że to ostatecznie przesądza datę urodzin Janczewskiej - 1889 rok (zapewne 25 lat skończyłaby w 1914 roku ${ }^{23}$. Dzień później potwierdza to notka:

Śp. Jadwiga Janczewska, córka mecenasa Wiktora Janczewskiego, b. posła ziemi mińskiej do pierwszej Izby państwowej, tragicznie zmarła w Zakopanem, została przewiezioną do naszego miasta i w dniu 20 lutego ( 5 marca) pochowaną na cmentarzu Kalwaryjskim. Liczny zastęp bliższych i dalszych znajomych odprowadził zwłoki z dworca Brzeskiego na cmentarz, gdzie po mszy złożono je do grobów rodzinnych ${ }^{24}$.

Widać tu, że ówcześni dziennikarze warszawscy i krakowscy nie tylko nie chcieli zmieniać doniesień innych tytułów, ale i nie zauważyli, że akurat ta informacja „Kuriera Litewskiego” z Wilna została opublikowana w dziale „Prowincja, Mińsk”. Stąd mylnie podawano, że pogrzeb odbył się w Wilnie.

Grób Janczewskiej jest (był?) zatem w Mińsku. Dzięki podziękowaniom rodziny, zamieszczonym w gazecie, wiadomo nawet, którzy z księży pomagali rodzinie $\mathrm{w}$ tych trudnych chwilach:

Wszystkim, którzy raczyli wziąć udział w odprowadzeniu drogich nam zwłok córki naszej śp. Jadwigi Janczewskiej i okazali nam tyle współczucia w ciężkich dla nas chwilach, a w szczególności Szanownym: ks. Dziekanowi Jagiełłowiczowi ${ }^{25}$ i ks. Proboszczowi Kucharskiemu ${ }^{26}$, składamy serdeczne „Bóg zapłać”. Rodzice²7.

$\mathrm{Na}$ rzymskokatolickim cmentarzu kalwaryjskim w Mińsku na Białorusi jest kilka grobów z nazwiskiem Janczewskich. Jednak wydaje się, że Jadwiga została złożona w grobie

S. I. Witkiewicz, Dzieła zebrane, t. 17: Listy I, s. 292, przypis 13 (Listy do Jadwigi Janczewskiej).

${ }^{22}$ „Kurier Litewski” 1914, nr 42 (z 20 lutego/5 marca), s. 1.

${ }^{23}$ "O kłopotach z datą urodzin Janczewskiej zob. S. Okołowicz, „Winy moje okropne”. Wokół samobójstwa Jadwigi Janczewskiej, s. 428 , przypis 5.

${ }^{24}$ „Kurier Litewski” 1914, nr 43 (z 21 lutego/6 marca), s. 3, dział „Prowincja, Mińsk”. i Zielonki.

${ }^{25}$ Prawdopodobnie chodzi o ks. Bolesława Jagiełłowicza (1871-1951), który od 1925 roku był związany z parafiami Wołomina

${ }^{26}$ Prawdopodobnie ks. Jan Kucharski, ówczesny proboszcz parafii kalwaryjskiej w Mińsku; T. Zienkiewicz, Polskie życie literackie w Mińsku w XIX i na początku XX wieku (do roku 1921), Olsztyn 1997, s. 127.

${ }^{27}$ „Kurier Litewski” 1914, nr 49 (z 28 lutego/13 marca), s. 1. 
w kwaterze oznaczonej numerem 223E, gdzie spoczywa Wincenty Janczewski (1805-1882). „Miejsce pochówku oznaczone skałką z naturalnego, różowego kamienia ustawioną na ziemi; na niej napis: »Ś.P. / Wincenty Janczewski / żył 77 lat / zm. 1882 r. /... Tu zwłoki leżą / dwóch braci rodzonych / Pamięć córki Wiktora «"28. Czy sformułowanie „pamięć córki Wiktora” oznacza, że grób jest tylko symboliczny? A może Janczewska, córka Wiktora Janczewskiego, została przeniesiona po I wojnie światowej do majątku Leszcze na Kujawach?

Leszcze na Kujawach (ówczesne Królestwo Polskie, gubernia kaliska, obecnie okolice Koła, Kłodawy i Przedcza, parafia Bierzwienna Długa) to miejsce, gdzie majątek mieli rodzice Jadwigi Janczewskiej. Przeprowadzili się tam na stałe po wojnie ${ }^{29}$. Zmarli zresztą niedługo po jej zakończeniu. Jadwiga z Wiewiórskich Janczewska w wieku lat 60 27 stycznia 1920 roku $^{30}$. Wiktor Janczewski zmarl we Frankfurcie nad Menem w sierpniu $1922 \mathrm{roku}^{31}$.

PS A tak wyglądał pod koniec XIX wieku kościół na Kalwarii, gdzie odprawiono za Jadwigę Janczewską mszę żałobną (na stronie internetowej, skąd pochodzi poniższe zdjęcie, można znaleźć wiele zdjęć cmentarza, w tym zdjęcie kaplicy grobowej z cegły w stylu neogotyckim z zachowanym napisem: „Grobowiec Witkiewiczów”):

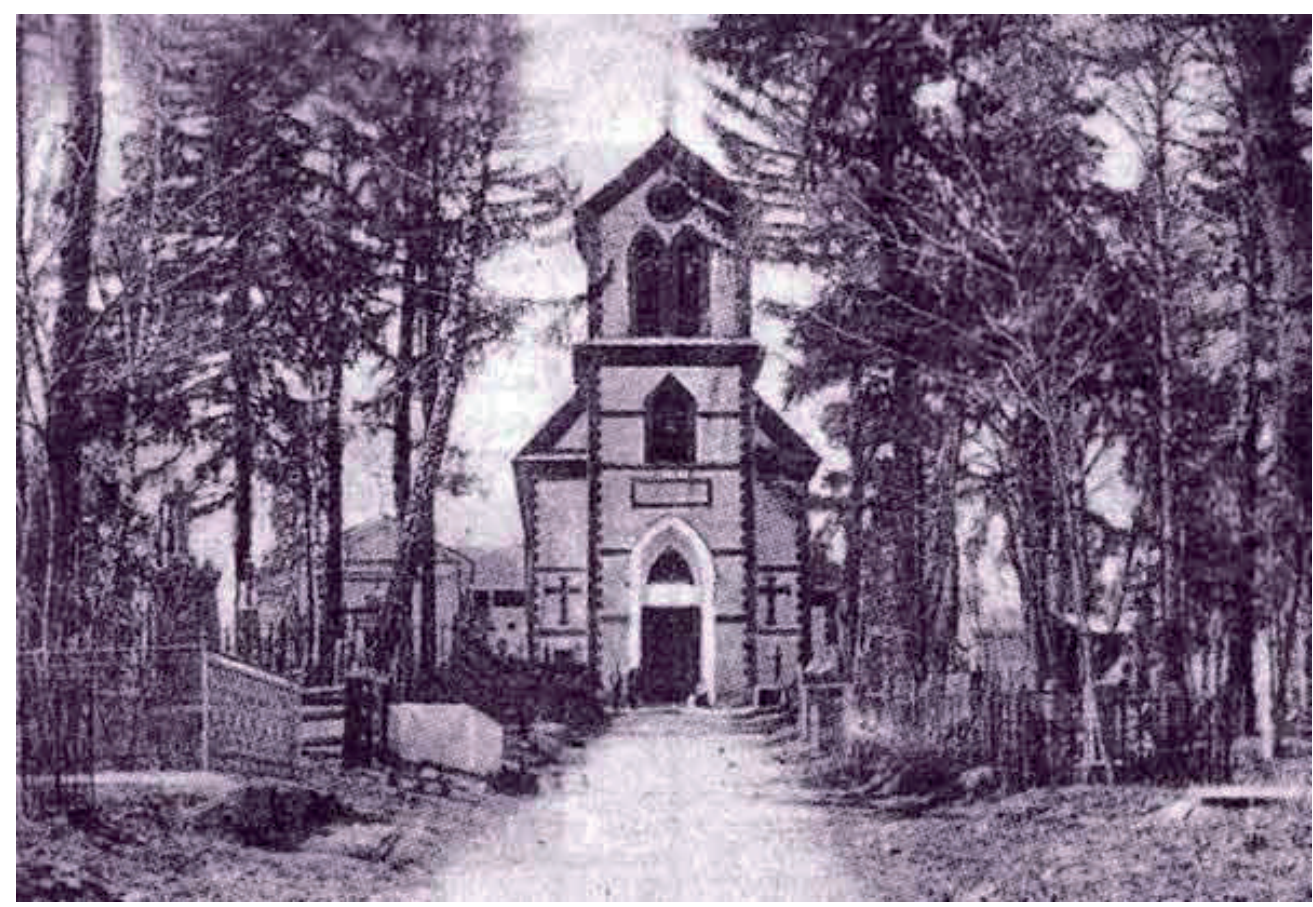

Kościół na Kalwarii; źródło: http://www.minsk-old-new.com/minsk-2722.htm (dostęp: 20.12.2013) poz. 901

${ }^{28}$ Rzymsko-katolicki cmentarz kalwaryjski w Mińsku na Białorusi, oprac. T. Czerniawska i A. Jaroszewicz, Warszawa 1996, s. 126,

${ }^{29}$ Witkacy tam zaadresował list do matki Jadwigi z 30 czerwca 1914 roku; S. I. Witkiewicz, Dzieła zebrane, t. 17: Listy I, s. 365 (Listy z tropików).

${ }^{30}$ Wyciąg z Księgi zgonów za rok 1920 parafii Bierzwienna, akt zgonu Jadwigi Janczewskiej, nr 14/20. Co ciekawe, w czerwcu tego samego roku zmarła Marta Janczewska, „wdowa, lat dwadzieścia dziewięć mająca, urodzona w mieście Mścisławiu Mohylowskiej guberni, córka Antoniego i Wiery z Leonowów, zamieszkała przy rodzeństwie w majątku Leszczach"; ibidem, nr aktu 57/20 (pisownia oryginalna).

${ }^{31}$ O czym zaświadczyli syn Janczewskiego, Leon, oraz rządca w majątku Leszcze, Aleksander Janczewski. Akt zgonu nr 55/22 w Księdze zgonów za rok 1922. 
Key Words: Stanisław Ignacy Witkiewicz (Witkacy), Jadwiga Janczewska, Warsaw University Library, "Kurier Warszawski”, “Nowa Reforma”, “Goniec Poranny”, “Goniec Wieczorny”, Cracow "Czas”, “Kurier Lwowski”, “Ilustrowany Kurier Codzienny”, “Dziennik Poznański”, “Gazeta Lwowska", "Gazeta Podhalańska”

Summary: The article presents and discusses press cut-outs concerning the suicide of Witkacy's fiancée, Jadwiga Janczewska. The query involved the journals stored in digital libraries and the journals from the archives of Warsaw University Library.

The first news on the suicide in the Tatra mountains appeared on Sunday 22 February 1914 in "Kurier Warszawski" (on the basis of a telegram by Eastern Telegraphic Agency from 21 February) and in Cracow's "Nowa Reforma", in which false information was given (first of all, the name of the deceased was wrong), as a result of which all national dailies published notes on the suicide of "Zofia Janczewska, age 22, from Lithuania”.

The Warsaw “Goniec Poranny”, “Goniec Wieczorny”, Cracow “Czas”, "Kurier Lwowski”, "Ilustrowany Kurier Codzienny”, "Dziennik Poznański”, "Gazeta Lwowska” or "Gazeta Podhalańska" often gave false information concerning the details of that tragic event (mistakes in reference to not only the name, but also surname of the deceased, her age and the place of burial). 